\title{
First Record of Pseudomyrmex acanthobius Emery in Brazilian Pantanal
}

\author{
Rodrigo Aranda ${ }^{1}$, Renan Olivier $^{2}$ \& Alexandre Ferraro ${ }^{3}$
}

1. Universidade Federal de Mato Grosso do Sul, e-mail: rodrigoaranda.biologo@gmail.com (Autor para correspondência ${ }^{\bowtie}$ ). 2. Programa de PósGraduação em Biologia Animal, Laboratório de Zoologia, Universidade Federal de Mato Grosso do Sul, e-mail: renanolivierg1@gmail.com. 3. Programa de Pós-Graduação em Biologia Vegetal, Universidade Federal de Mato Grosso do Sul, e-mail: alxferraro@gmail.com.

\section{EntomoBrasilis 9 (1): $56-58$ (2016)}

\section{Registered in the ZooBank: urn:lsid:zoobank.org:pub:270AF11F-FDD9-416E-B9DE-94C8B91E2B68}

Abstract. Associations between ants and plants may be described, in some cases, as mutualisms. Ants use plant structures as sites for nesting and in return they offer protection against herbivory. This paper reports for the first time the association between Pseudomyrmex acanthobius Emery nest in subterranean structures of Aspilia grazielae J.U.Santos, an endangered endemic plant species, in Corumbá, Pantanal domain. Additionally, this record reveals a new aspect of the ecological niche and extends the geographic distribution of $P$. acanthobius.

Keywords: Aspilia grazielae; Interaction; Pseudomyrmicinae; Xylopodium.

\section{Primeiro Registro de Pseudomyrmex acanthobius Emery no Pantanal Brasileiro}

Resumo. A associação entre formigas e plantas pode ser descrita em alguns casos como mutualismo. Estruturas de plantas, como locais de nidificação, atraem algumas espécies de formigas em troca da proteção anti-herbivoria. Este trabalho registra pela primeira vez a nidificação de Pseudomyrmex acanthobius Emery em estrutura subterrânea de Aspilia grazielae J.U.Santos, espécie endêmica e ameaçada de extinção na região de Corumbá, no domínio Pantanal. Adicionalmente, esse registro revela nova amplitude do nicho ecológico e amplia a distribuição geográfica prevista de P. acanthobius

Palavras-Chave: Aspilia grazielae; Interação; Pseudomyrmicinae; Xylopodium.

$\mathbb{M}$ any ant species have mutualistic relationships with plants, using structures for nest construction in return for anti-herbivory defense (HöLLDOBLER \& WILSON 1990; Rico-Gray et al. 2010). Plants provide nesting cavities and food rewards for opportunistic ants (ANDERSON \& McSHEA 2001; Rico-Gray \& Oliveira 2010). The subfamily Pseudomyrmecinae has three genera of which Pseudomyrmex is the most common and exclusive to the Neotropics. The majority of species of Pseudomyrmex are tree-dwelling organisms and exhibit intimate mutualistic relationships with several plants species, building its nests inside specialized structures called domatias (hollow thorns, petioles, stems, rhizomes/tubers or modified leaves) our hollow things (Hölldobler \& Wilson 1990; Davidson \& McKeY 1993; BOLTON 1994; MAYER et al. 2014).

The name Pseudomyrmex acanthobius Emery originates from the typical habit of this species to live on thorns (gr. akanthos, 'thorns' + bios, 'life') that are commonly found in aerial structures of plants. This species is easily distinguished by the black edge of the jaws and eyes, the unique upper part of the peduncle, and the large brownish segments of the gaster (GALLARDO 1932) (Figure 1A).

In Brazil, this species was recorded only in Rio Grande do Sul state, in cities and natural grassland (Fields), associated with individuals of Caesalpinia ferrea Mart. ex. Tul. and Inga vera Willd. (Fabaceae), Tabebuia chysotricha (Mart. ex A. DC.) Stamdl. and Tabebuia rosea (Bertol.) DC. (Bignoniaceae), as well as wood hollow (Diehl et al. 2006; Pinheiro et al. 2010). In this paper we report a nest of Pseudomyrmex acanthobius occurring into the xylopodium of Aspilia grazielae J.U. Santos (Asteraceae) in the Pantanal domain.
The Pantanal domain is the biggest flood plain of world in the central-west region of Brazil, covering an area of $150,000 \mathrm{~km}^{2}$, and contains about $40 \%$ of the Upper Paraguay River Basin (Aв'SABER 1977). In this domain, the Maciço do Urucum region displays remarkable characteristics, due to different latitudinal and altitudinal gradients that alter the composition of its fauna and flora. This region is considered ecotonal, due to the influences from surrounding ecosystems, with elements of Savanna (Cerrado), Amazon Forest, and Steppic Savanna (Chaco), with some species restricted to this area (AB'SABER 1977).

The Aspilia grazielae J.U.Santos is an endemic species in the Maciço do Urucum region ( $19^{\circ} 11^{\prime} 05$ "S $/ 57^{\circ} 36^{\prime} 17^{\prime \prime W}, 850 \mathrm{~m}$ ) (SANTOS 1987), occurring in areas of 700 meters above sea level, in shrubby typical Cerrado. Thirty-five individuals of $A$. grazielae (in 13.ix.2012) containing reproductive and resistance structures were collected (deposited in CGMS Herbarium code CGMS 40810). During the morphological analysis of these individuals we detected the presence of ants in xylopodium. This structure was dissected in six parts, and the collected ants were placed in alcohol 70\% and deposited in the Coleção Zoológica de Referência da Universidade Federal de Mato Grosso do Sul (code CEUFMS 11205).

We report for the first time a colony of $P$. acanthobius inside the xylopodium of one individual of $A$. grazielae (Figure $1 \mathrm{~B}$ and $\mathrm{C}$ ), in which 74 ants were observed (54 larvae in different development stages, 15 pupae, four workers and one queen). In a similar study, with Pseudomyrmex concolor Smith, FonsECA (1993) the establishment of nests made by one or few queens was observed, as well as the number of individuals at different stages which seemed to be an important indicator of colony development. 
T con Considering the proportions of individuals from each caste that we observed, the nest found indicates an initial development of $P$. acanthobius colony. The nest had no chamber or modification in the basic structure of root, being compound only in a tubular gallery with one aerial entrance and a subterranean entrance above the xylopodium area (Figure 1C).

The specie $P$. acanthobius was commonly reported in aerial structures (e.g. thorns) (GALLARDO 1932), therefore, it may have a wider ecological niche than previously presumed. This record also extends the geographic distribution of this species to the Pantanal domain. Studies from other Latin American countries such as Mexico, Caribbean, Belize, Costa Rica, Venezuela [on Theobroma cacao L. (Malvaceae)], Nicaragua, and the Paraguayan Chaco, also reported nests frequently in swollenthorns of Acacia sp. (Fabaceae) (JAFFE et al. 1986; MAES \& Mackay 1993; Delsine et al. 2007; WiLd 2007). The influence of the Chaco floristic composition in the flora of Maciço do Urucum, through transitional areas of Steppic Savanna with decidual and semidecidual Forests, respectively (Lima 2008), can help to understand this record of $P$. acanthobius.

Asteraceae individuals can accumulate Inulin-type fructans as carbohydrate storage (ERNST et al. 1996). In other species, other structures, such as extrafloral nectaries, are used for ant attraction, giving nutrients in exchange of protection (BENTLEY 1976; Deuth 1980; KeLLy 1986), and carbohydrates from xylopodium storage may be attractive to ants and was, once reported as a preferential substance in ant foraging (BLUTHGEN \& FIEDLER 2004). The Maciço do Urucum is characterized as a rupestrian field region of Cerrado and the frequent hydric stress is a potential factor that could enhance the interaction between $P$. acanthobius and A. grazielae, which provides shelter and food resources to this ant species, and increases the colony fitness (ByK \& DeL-Claro 2011). Myrmecophytes plants have structures highly specialized for the establishment of nests and resources supplying (domatias) (Guimarães et al. 2007; Dátillo et al. 2009), however for A. grazielae, the structures are absent. Thus, the relation between $P$. aconthobius and A. grazielae probably comprises the subterranean structure food resource. The variation of abiotic factors (in the case of the Maciço do Urucum rupestrian field region) can increase the association of ants in a non-myrmecophytes species (RIco Gray et al. 2012).

Pseudomyrmex ants are widely known to nest in the tree layer, and, furthermore, the lack of literature about subterranean structures and insect fauna relationships makes this the first record of $P$. acanthobius nesting inside a xylopodium.
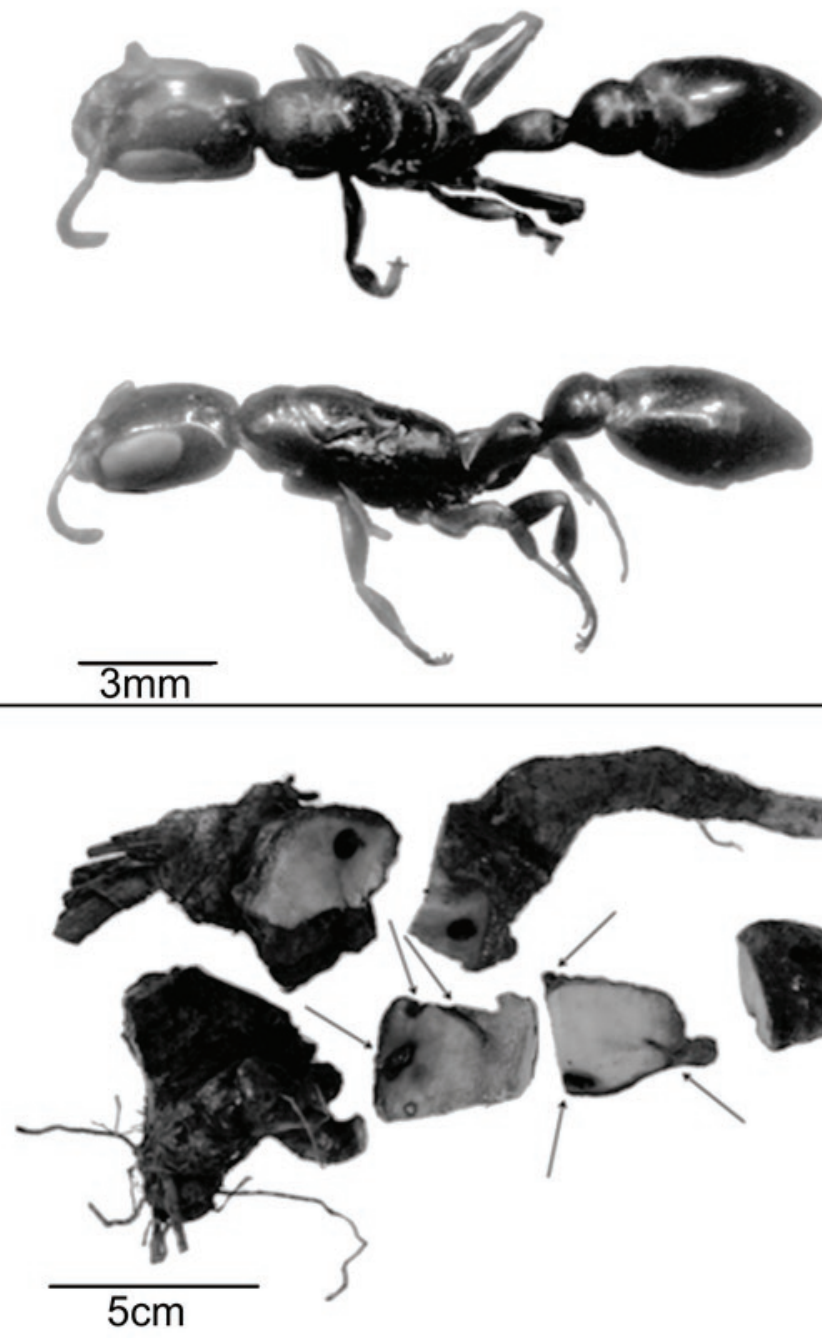
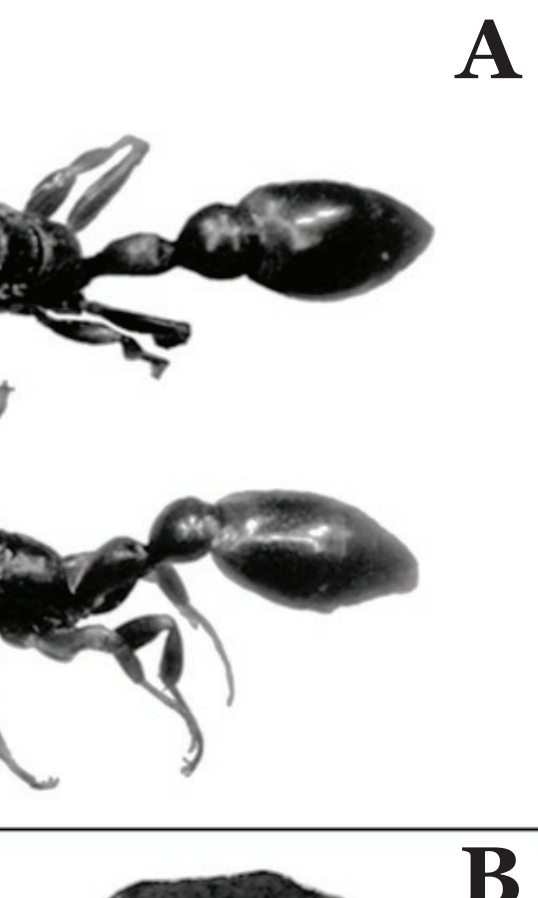

î

Figure 1. A - Queen of Pseudomyrmex acanthobius in xylopodium of Aspilia grazielae in Maciço do Urucum, Corumbá, Mato Grosso do Sul. Scale bar $=3 \mathrm{~mm}$; B - Xylopodium of Aspilia grazielae with nest of Pseudomyrmex acanthobius. Scale bar $=5 \mathrm{~cm}$; arrows indicate galleries of nest; C - Nest mold in silicone with indication of aerial and terrestrial parts and entrances of nest. Scale bar $=1 \mathrm{~cm}$. 


\section{ACKNOWLEDGEMENTS}

We thank Dr. Paulo Robson de Souza for identifying the ant species, Carlos Rodrigo Lehn for additional information about the biology and conservation of plants, and Rosa Helena da Silva for the botanical collections.

\section{REFERENCES}

Ab’Saber, A.W., 1977. Os domínios morfoclimáticos na América do Sul: Primeira aproximação. Geomorfologia, 5: 1-21.

Anderson, C. \& D.W. McShea, 2001. Intermediate-level parts in insect societies: adaptive structures that ants build away from the nest. Insect Sociaux, 48:2 91-30.1

Bentley, B.L., 1976. Plants bearing extrafloral nectaries and the associated ant community: Interhabitat differences in the reduction of herbivore damage. Ecology, 57: 815-820.

Bluthgen, N. \& K. Fiedler, 2004. Preferences for sugars and amino acids and their conditionality in a diverse nectar-feeding ant community. Journal of Animal Ecology, 73: 155-166.

Bolton, B., 1994. Identification guide to the ant genera of the World. Cambridge, Harvard University Press, 222p.

Byk, J. \& K. Del-Claro, 2011. Ant-plant interaction in the Neotropical savanna: direct beneficial effects of extrafloral nectar on ant colony fitness. Population Ecology, 53: 327332.

Dáttilo, W., E.C. Marques, J.C.F. Falcão \& D.D.O Moreira, 2009. Interações mutualísticas entre formigas e plantas. EntomoBrasilis, 2: 32-36.

Davidson D.W. \& D. McKey, 1993. The evolutionary ecology of symbiotic ant-plant relationships. Journal of Hymenoptera Research, 2: 13-83.

Delsine, T., Y. Roisin \& M. Leponce, 2007. Spatial and temporal foraging overlaps in a Chacoan ground-foraging ant assemblage. Journal of Arid Environments, 71: 29-44.

Deuth, D.A., 1980. The protection of Cassia fruticosa (Leguminosae) from herbivores by ants foraging at the foliar nectaries. Masters Thesis - University of Colorado. 86 p.

Diehl, E., C.L. Göttert \& D.G. Flores, 2006. Comunidades de formigas em três espécies utilizadas na arborização urbana em São Leopoldo, Rio Grande do Sul, Brasil. Bioikos, 20: 2532.

Ernst, M., J. Chatterton \& P.A. Harrison, 1996. Purification and characterization of a new fructan series from species of Asteraceae. New Phytologist, 132: 63-66.

Fonseca, C.R., 1993. Nesting space limits colony size of the plantant Pseudomyrmex concolor. Oikos, 67: 473-482.
Gallardo, A., 1932. Las hormigas de la República Argetina. Subfamilia mirmicinas, sección Promyrmicinae. Anales Del Museo Nacional de Historia Natural, 37: 37-88.

Guimarães, P.R., V. Rico-Gray, P.S. Oliveira, T.J. Izzo, S.F. Reis \& J.N. Thompson, 2007. Interaction intimacy affects structure and coevolutionary dynamics in mutualistic networks. Current Biology, 17: 1797-1803.

Hölldobler, B. \& E.O. Wilson, 1990. The ants. Cambridge, Harvard University Press, $732 \mathrm{p}$.

Jaffe, K., P.A. Tablante \& P. Sanchez, 1986. Ecología de Formicidae em plantaciones de cação em Barlovento, Venezuela. Revista Theobroma, 16: 189-197.

Kelly, C.A. 1986. Extrafloral nectaries: ants, herbivores and fecundity in Cassia fasciculata. Oecologia, 69: 600-605.

Lima - Laboratório Interdisciplinar de Meio Ambiente, 2008. Avaliação Ambiental Estratégica do Pólo Minero-Industrial de Corumbá e influências sobre a planície pantaneira. Rio de Janeiro, LIMA/COPPE/UFRJ, 544 p. Available in: $<$ https://www.lima.coppe.ufrj.br/aaepantanal/>. [Access in: 09.19.2015].

Maes, J.M. \& W.P. Mackay, 1993. Catalogo de lãs hormigas (Hymenoptera: Formicidae) de Nicaragua. Revista Nicaraguense de Entomologia, 23: 1-46.

Mayer, V.E., M.E. Frederickson, D. McKey \& R. Blatrix. 2014. Current issues in the evolutionary ecology of ant-plant symbioses. New Phytologist, 202: 749-764.

Pinheiro, E.R.S., L.S. Duarte, E. Diehl \& S.M. Hartz, 2010. Edge effects on epigeic ant assemblages in a grassland forest mosaic in southern Brazil. Acta Oecologica, 36: 365-371.

Rico-Gray, V. \& P.S. Oliveira, 2010. The ecology and evolution of ant-plant interactions. Austral Ecology, 35: 116-119.

Rico-Gray, V., C. Díaz-Castelazo, A. Ramírez-Hernández, P.R. Guimarães-Jr \& J.N. Holland, 2012. Abiotic factors shape temporal variation in the structure of an ant-plant network. Arthropod-Plant Interactions, 6: 289-295.

Santos, J.U.M., 1987. Aspilia Thou. (Compositae: Heliantheae). Novidades taxonômicas do gênero. III. Boletim do Museu Paraense Emílio Goeldi, 3: 51-58.

Wild, A.L., 2007. A catalogue of the ants of Paraguay (Hymenoptera: Formicidade). Zootaxa, 1622: 1-55.

\section{Received in: 20.v.2015}

Accepted in: $21 . x i .2015$

\section{Suggestion citation:}

Aranda, R., R. Olivier \& A. Ferraro, 2016. First Record of Pseudomyrmex acanthobius Emery in Brazilian Pantanal. EntomoBrasilis, 9 (1): 56-58. Available in: doi:10.12741/ebrasilis.vgi1.535
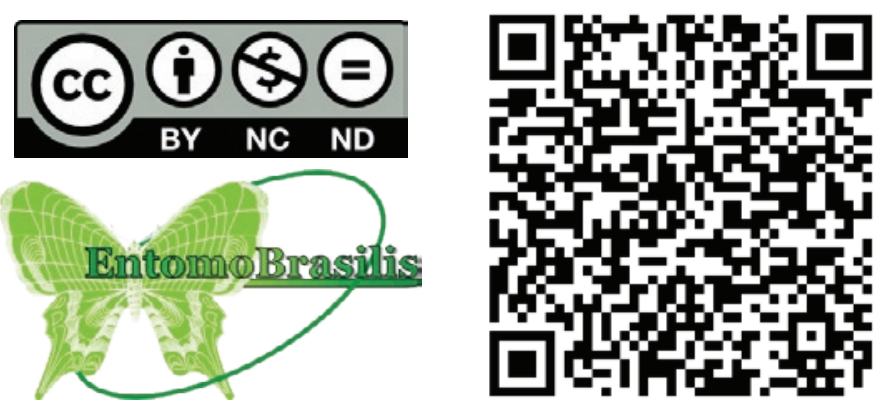